\title{
Allergic Inflammation in Isolated Vagal Sensory Ganglia Unmasks Silent NK-2 Tachykinin Receptors
}

\author{
Daniel Weinreich, Kimberly A. Moore, and Glen E. Taylor \\ Department of Pharmacology and Experimental Therapeutics, School of Medicine, University of Maryland, \\ Baltimore, Maryland 21201-1559
}

Neuroplastic changes in vagal afferents inflicted by allergic inflammation were examined in nodose ganglia (NG) removed from guinea pigs immunized to chick ovalbumin. In control NG neurons, substance P (SP; 0.1-10 $\mu \mathrm{M}$ ) produces no discernable changes in membrane electrophysiological properties or $\left[\mathrm{Ca}^{2+}\right]_{\mathrm{i}}$. After exposing $\mathrm{NG}$ from immunized animals to the sensitizing antigen in vitro, $83 \%$ of the neurons were depolarized by $100 \mathrm{~nm}$ SP. SP also produces an inward current, an increase in membrane conductance, and an elevation of $\left[\mathrm{Ca}^{2+}\right]_{\mathrm{i}}$. Buffering $\left[\mathrm{Ca}^{2+}\right]_{\mathrm{i}}$ with BAPTA blocked the $\left[\mathrm{Ca}^{2+}\right]_{\mathrm{i}}$ rise and the SP depolarization, indicating that internal stores of $\mathrm{Ca}^{2+}$ are required. When protein synthesis was inhibited $>96 \%$ (as determined by $\left[{ }^{3} \mathrm{H}\right]$ leucine incorporation), antigen challenge still unmasked SP responses. The SP response was maximal 30 min after antigen challenge, and it was evident for at least 8 $\mathrm{hr}$ in intact ganglia and for $3.5 \mathrm{~d}$ in isolated neurons. [ $\beta$ -
Ala $\left.^{8}\right]$ Neurokinin A ( $\left.\left[\beta-\mathrm{Ala}^{8}\right] \mathrm{NKA} ; 10 \mathrm{~nm}\right)$, an NK-2 selective agonist, mimicked SP; selective NK-1 and NK-3 agonists were ineffective. The $\mathrm{EC}_{50}$ values for SP and $\left[\beta-\mathrm{Ala}^{8}\right] \mathrm{NKA}$ membrane currents were 78 and $33 \mathrm{nM}$, respectively. Additionally, SR48968, an NK-2 receptor antagonist, blocked these responses. Thus, antigen challenge appears to unmask an NK-2 tachykinin receptor. These data further support the hypothesis that inflammatory mediators released during immediate hypersensitivity (allergic) reactions can produce profound effects on the excitability of sensory nerves. Unmasked NK-2 receptors may serve an excitatory autoreceptor function, provide a pathway for paracrine signaling between NG neurons, and contribute to ectopic sensory nerve activity.

Key words: sensory neuron; substance $P$; nerve injury; tachykinin receptors; inflammation; mast cells; immediate hypersensitivity
Inflammation induced by chemical irritants or by nerve damage causes profound alterations in primary afferent neurons ranging from sensitization of transduction processes at nerve endings (Meyer et al., 1994) to neuroanatomical remodeling of nerve arbors (Stead and Bienenstock, 1990). Despite the belief that some symptoms of allergic inflammatory diseases are mediated by abnormalities in sensory neurons (Barnes et al., 1990; Marshall and Waserman, 1995), relatively little is known about the types of neuroplastic changes in sensory neurons inflicted by allergic inflammation.

In vivo and in vitro studies of allergic inflammation in the guinea pig airways have provided valuable information about the nature of immunomodulation of airway sensory neurons (Pedersen et al., 1997). For example, $12 \mathrm{hr}$ after exposing airways from actively sensitized animals to nebulized allergen, the levels of preprotachykinin A mRNA increased in vagal sensory neurons (nodose neurons). By $24 \mathrm{hr}$, airway tachykinin levels are increased fourfold, and the number of nodose neurons expressing tachykinins have increased by $\sim 25 \%$; most were identified as airway afferents by retrograde labeling. Thus, allergic inflammation can cause a dramatic phenotypic switch in the tachykinin expression

\footnotetext{
Received June 9, 1997; revised Aug. 1, 1997; accepted Aug. 5, 1997.

This work was supported by United States Public Health Service Grant NS 22069 to D.W. and Neuroscience Training Grant NS 07375 to K.A.M. We thank Drs. Brendan Canning and Brad Undem for constructive suggestions on an earlier draft of this manuscript.

Correspondence should be addressed to Dr. Daniel Weinreich, University of Maryland, School of Medicine, Department of Pharmacology and Experimental Therapeutics, Room 522B, Health Sciences Facility, 685 West Baltimore Street, Baltimore, MD 21201-1559.

Copyright (C) 1997 Society for Neuroscience $\quad 0270-6474 / 97 / 177683-11 \$ 05.00 / 0$
}

of vagal afferents (Fischer et al., 1996; cf. Neumann et al., 1996). Allergic inflammation can also change the transduction process at vagal afferent nerve endings. Exposing trachea isolated from immunized guinea pigs to a sensitizing antigen activates mast cells and increases the mechanosensitivity of $\mathrm{A} \delta$ vagal afferent airway nerve endings approximately fourfold (Riccio et al., 1996).

Allergen-induced neuroplastic changes can also be provoked in nodose ganglia isolated from actively sensitized guinea pigs. Nodose ganglia possess mast cells that can release numerous preformed and newly synthesized inflammatory mediators when challenged with a sensitizing antigen. Intracellular recording from nodose neurons after antigen challenge reveals myriad excitability changes, including (1) membrane depolarization, (2) increases and decreases in resting membrane conductance, (3) inhibition of a time- and voltage-dependent inward rectifying current, and (4) block of a slow postspike afterhyperpolarization $\left(\mathrm{AHP}_{\text {slow }}\right)$ (Undem et al., 1993). Similar membrane effects were observed when purified lung mast cells were immunologically activated and their lysates applied to control nodose ganglion neurons (Greene et al., 1988). Thus, nodose ganglia isolated from immunized guinea pigs provide a model for understanding, at the cellular level, how allergic inflammation modifies voltage- and ligand-gated ionic channels in primary sensory neurons. Additionally, nodose neurons serve as a model for studying the transduction properties of the less accessible peripheral nerve endings.

During the process of examining whether nodose ganglia might be a suitable model for clarifying the pathways underlying allergen-induced expression of tachykinins, we discovered, serendipitously, that antigenic inflammation caused a rapid unmasking of tachykinin receptors. In control or nonchallenged nodose gan- 
glia, exogenously applied tachykinins never elicited detectable electrophysiological changes. However, $30 \mathrm{~min}$ after antigen challenge to nodose ganglia from sensitized animals, and persisting for several days, tachykinin application evoked membrane depolarization, increased membrane conductance, and elevated $\left[\mathrm{Ca}^{2+}\right]_{\mathrm{i}}$ in $>83 \%$ of nodose neurons. The current work physiologically and pharmacologically characterizes this new form of immunomodulation of sensory neurons.

\section{MATERIALS AND METHODS}

Sensitization of animals. Adult male Hartley guinea pigs (150-200 gm; Charles River, Wilmington, MA) were actively sensitized to ovalbumin (chicken egg albumin; Sigma Chemical Co., St. Louis, MO) as described previously (Weinreich and Undem, 1987). Briefly, animals were injected intraperitoneally with ovalbumin $(10 \mathrm{mg} / \mathrm{kg})$ every other day for a total of three injections. Twenty-one to $65 \mathrm{~d}$ after the last injection, animals were killed by asphyxiation with $\mathrm{CO}_{2}$. Nodose ganglia were dissected bilaterally and placed in ice-cold $\left(4^{\circ} \mathrm{C}\right)$ Locke solution (composition in mM: $136 \mathrm{NaCl} ; 5.6 \mathrm{KCl} ; 1.2 \mathrm{MgCl}_{2} ; 2.2 \mathrm{CaCl}_{2} ; 14.3 \mathrm{NaHCO}_{3} ; 1.2$ $\mathrm{NaH}_{2} \mathrm{PO}_{4}$; and 10 dextrose) equilibrated with $95 \% \mathrm{O}_{2}$ and $5 \% \mathrm{CO}_{2}, \mathrm{pH}$ 7.2-7.4.

Antigenic challenge. Nodose ganglia were prewarmed to $37^{\circ} \mathrm{C}$ in Locke solution for $10 \mathrm{~min}$ and then transferred to Locke solution containing 10 $\mu \mathrm{g} / \mathrm{ml}$ antigen [chick ovalbumin (OVA)] or control proteins (bovine serum albumin or human serum albumin) for 15 min. After challenge with OVA or control protein, ganglia were returned to Locke solution for at least $15 \mathrm{~min}$ before transfer to the recording chamber or preparation for enzymatic dissociation.

To test whether animals were actively sensitized, superior cervical ganglia (SCG) were removed along with nodose ganglia. After antigen challenge, SCG removed from actively sensitized guinea pigs reveal antigen-induced long-term potentiation (A-LTP) of synaptic transmission (Weinreich et al., 1995). We used this bioassay to determine that animals were sensitized successfully. In all actively sensitized animals in which the SCG showed A-LTP, allergen-induced physiological changes were observed in the nodose ganglia.

Role of inflammatory mediators. To test the involvement of various inflammatory mediators, one of a pair of nodose ganglia, removed from a sensitized animal, was incubated with either a cyclooxygenase inhibitor (indomethacin, $3 \mu \mathrm{M}$ ), a 5'-lipoxygenase inhibitor (ZD2138, $3 \mu \mathrm{M})$, or a mixture of $\mathrm{H}-1, \mathrm{H}-2$, and $\mathrm{H}-3$ histamine receptor antagonists (pyrilamine, $1 \mu \mathrm{M}, \mathrm{H}-1$; burimamide, $50 \mu \mathrm{M}, \mathrm{H}-2$ and $\mathrm{H}-3) 10$ min before and during antigenic challenge. The other ganglion of the pair served as a control and was treated as described above, except that vehicle was substituted for drugs.

Protein synthesis. Inhibition of protein synthesis was monitored by measuring incorporation of $\left[{ }^{3} \mathrm{H}\right]$ leucine into protein. Nodose ganglia were incubated for $60 \mathrm{~min}$ in $1 \mathrm{ml}$ of normal Locke solution or Locke solution containing $100 \mu \mathrm{g} / \mathrm{ml}$ cycloheximide. Fifty $\mu \mathrm{Ci}$ of $\left[{ }^{3} \mathrm{H}\right]$ leucine $(180 \mathrm{Ci} / \mathrm{mmol})$ were then added to each tube containing a ganglion. After an additional $60 \mathrm{~min}$ at $37^{\circ} \mathrm{C}$, ganglia were washed three times with isotope-free, ice-cold Locke solution and then homogenized in 5\% trichloracetic acid (TCA). Homogenates were pipetted onto glass filters and washed three times with ice-cold 5\% TCA. After drying, the filters were counted using a scintillation counter. In three experiments, the incorporation of $\left[{ }^{3} \mathrm{H}\right]$ leucine into protein was inhibited $96 \pm 0.6 \%$ (range, 95-97\%).

Tissue Preparation. For experiments with intact ganglia, adhering connective tissue was carefully removed. The ganglion was slit longitudinally with a razor blade fragment and pinned to the Sylgard (Dow Corning Co., Midland, MI)-coated floor of the recording chamber $(\sim 0.25 \mathrm{ml}$ volume). Ganglia were superfused continuously with oxygenated Locke solution $(3-5 \mathrm{ml} / \mathrm{min})$ maintained at $35-37^{\circ} \mathrm{C}$.

Acutely dissociated neurons were prepared enzymatically as described by Christian et al., (1993). Neuronal cell suspensions (0.15-0.25 ml) were transferred onto circular 15 or $25 \mathrm{~mm}$ polylysine $(0.1 \mathrm{mg} / \mathrm{ml}$ poly-Dlysine, Sigma)-coated glass coverslips (Fisher Scientific, Houston, TX) and maintained at $37^{\circ} \mathrm{C}$ for at least $8 \mathrm{hr}$ before intracellular recording.

Electrode fabrication, recording chamber, and drug delivery. Intracellular glass recording micropipettes were fabricated on a Flaming-Brown P-97 micropipette puller (Sutter Instrument Co., San Francisco, CA).

For intracellular recordings from intact nodose neurons, ganglia were pinned to the floor of a Sylgard-lined recording chamber mounted on a fixed stage microscope equipped with Hoffman optics $(400 \times)$. For recording from isolated nodose neurons, a custom recording chamber was designed to provide superfusion of the coverslip with Locke solution via a gravity flow system. The superfusate level was lowered to $\sim 50 \mu \mathrm{m}$ above the surface of the neurons with an adjustable aspirator to minimize electrode stray capacitance. The chamber was mounted on the stage of an inverted microscope (IM 35; Carl Zeiss Inc., Thornwood, NY) equipped with a $40 \times$ oil immersion objective (Zeiss Fluar; numerical aperture, 1.3) to allow direct visualization of neurons for intracellular impalement and fluorescence measurements.

Reservoirs containing various drugs were connected to the inflow line of the recording chamber with three-way valves that could rapidly divert the source of superfusion from the main reservoir. This method of drug delivery introduced a $30 \mathrm{sec}$ delay from the activation of the valve to arrival of drug solution at the chamber. Agonists were superfused over ganglia or isolated neurons for $30-60 \mathrm{sec}$. When receptor antagonists were used, ganglia or neurons were superfused with these reagents for at least $5 \mathrm{~min}$ before the addition of agonists. The temperature of the recording chamber was maintained at $35-37^{\circ} \mathrm{C}$, unless noted otherwise.

Preparation of drug solutions and sources. Drug solutions were prepared daily from concentrated $(>10 \mathrm{~mm})$ stocks stored at $-20^{\circ} \mathrm{C}$. CP99,994 was provided by Dr. Jim Heyn (Pfizer, Inc. Groton, CT), SR48968, SR142801, senktide analog ([Asp ${ }^{6,7}$, methyl-Phe $\left.^{8}\right]$ substance $\mathrm{P}(6-11)$ ), ASM-SP $\left(\operatorname{Ac}\left[\operatorname{Arg}^{6}, \operatorname{Sar}^{9}, \operatorname{Met}\left(\mathrm{O}_{2}\right)^{11}\right] \mathrm{SP}(6-11)\right)$, and ZD2138 were gifts from Zeneca (Wilmington, DE), and burimamide was a gift from SmithKline Beecham (Philadelphia, PA). All other reagents were purchased from Sigma. The same lot number of ovalbumin used to sensitize an animal was used for antigenic challenge of the nodose ganglia.

Electrophysiological recording. Standard intracellular stimulating and recording techniques were used to monitor electrical activity with aluminosilicate intracellular micropipettes $(20-50 \mathrm{M} \Omega$ when filled with $3 \mathrm{M}$ $\mathrm{KCl})$. Current- and voltage-clamp recordings were made with an Axoclamp-2A amplifier (Axon Instruments, Foster City, CA) either in bridge (filtering at $10 \mathrm{kHz}$ ) or discontinuous mode (sample rate, $5 \mathrm{kHz}$; filtered at $0.3-3 \mathrm{kHz}$ ); headstage voltage was monitored continuously. Current and voltage signals were viewed on-line with an oscilloscope and digitized with a Neurocorder (NeuroData Instruments, Inc., Delaware Water Gap, PA) for storage on videocassette for off-line analysis. Membrane input resistance of the cell was monitored by measuring the magnitude of electrotonic voltage transients produced by $100 \mathrm{pA}$ hyperpolarizing current pulses $(100-300 \mathrm{msec})$. Neurons were accepted for study only if they showed a stable resting membrane potential $(\leq-50$ $\mathrm{mV}$ ) throughout the experiment, an action potential overshoot $>20 \mathrm{mV}$, and a membrane input resistance $>30 \mathrm{M} \Omega$. Data acquisition and analysis of electrophysiological data were performed using pClamp 6.2 software with a Digidata 1200 interface (Axon Instruments).

$\left[\mathrm{Ca}^{2+}\right]_{\mathrm{i}}$ measurement. To measure $\left[\mathrm{Ca}^{2+}\right]_{\mathrm{i}}$, cells on coverslips were incubated for $75-90 \mathrm{~min}$ at room temperature $\left(22-24^{\circ} \mathrm{C}\right)$ in a solution containing $1 \mu \mathrm{M}$ fura-2 AM as described previously (Cohen et al., 1997). After incubation, the coverslip was placed in the recording chamber and superfused with Locke solution. Fura-2 fluorescence measurements were performed with a DeltaScan illumination system [Photon Technology International (PTI), South Brunswick, NJ] coupled to the microscope through a fiber optic cable. Each neuron under study was alternately illuminated with 340 and $380 \mathrm{~nm}$ light, and the fluorescence emission, after passing through a $510 \mathrm{~nm}$ bandpass filter, was sampled by a photomultiplier tube, the output from which was digitized and stored for subsequent analysis. Instrument control, data acquisition, and analysis were performed using FELIX 1.1 software (PTI).

$\left[\mathrm{Ca}^{2+}\right]_{i}$ calibration. Values of intracellular $\left[\mathrm{Ca}^{2+}\right]_{\mathrm{i}}$ were derived using the ratio method of Grynkiewicz et al. (1985). All fura-2 fluorescence records were corrected for background fluorescence by subtracting the light intensity measured from neurons depleted of fura- 2 by digitonin permeabilization (Kao, 1994). $\left[\mathrm{Ca}^{2+}\right]_{\mathrm{i}}$ was calculated using the equation of Grynkiewicz et al. (1985):

$$
\left[\mathrm{Ca}^{2+}\right]_{\mathrm{i}}=K_{\mathrm{d}} \times\left[\left(R-R_{\min }\right) /\left(R_{\max }-R\right)\right] \times\left[\left(S_{\mathrm{f} 2}\right) /\left(S_{\mathrm{b} 2}\right)\right],
$$

where $R$ is the ratio $F_{340} / F_{380}$, and $R_{\min }$ and $R_{\max }$ are the minimum and maximum values of the ratio, attained at zero and saturating $\mathrm{Ca}^{2+}$ concentrations, respectively. $F_{340}$ is the fluorescence emitted by the dye when excited at $340 \mathrm{~nm}$, and $F_{380}$ is the fluorescence emitted by the dye when excited at $380 \mathrm{~nm} . S_{\mathrm{f} 2} / S_{\mathrm{b} 2}$ is the ratio of fluorescence intensities for $\mathrm{Ca}^{2+}$-free and $\mathrm{Ca}^{2+}$-bound indicator measured with $380 \mathrm{~nm}$ excitation. $R_{\text {min }}, R_{\text {max }}$, and $S_{\mathrm{f} 2} / S_{\mathrm{b} 2}$ were determined from five acutely dissociated neurons used specifically for calibration purposes. 

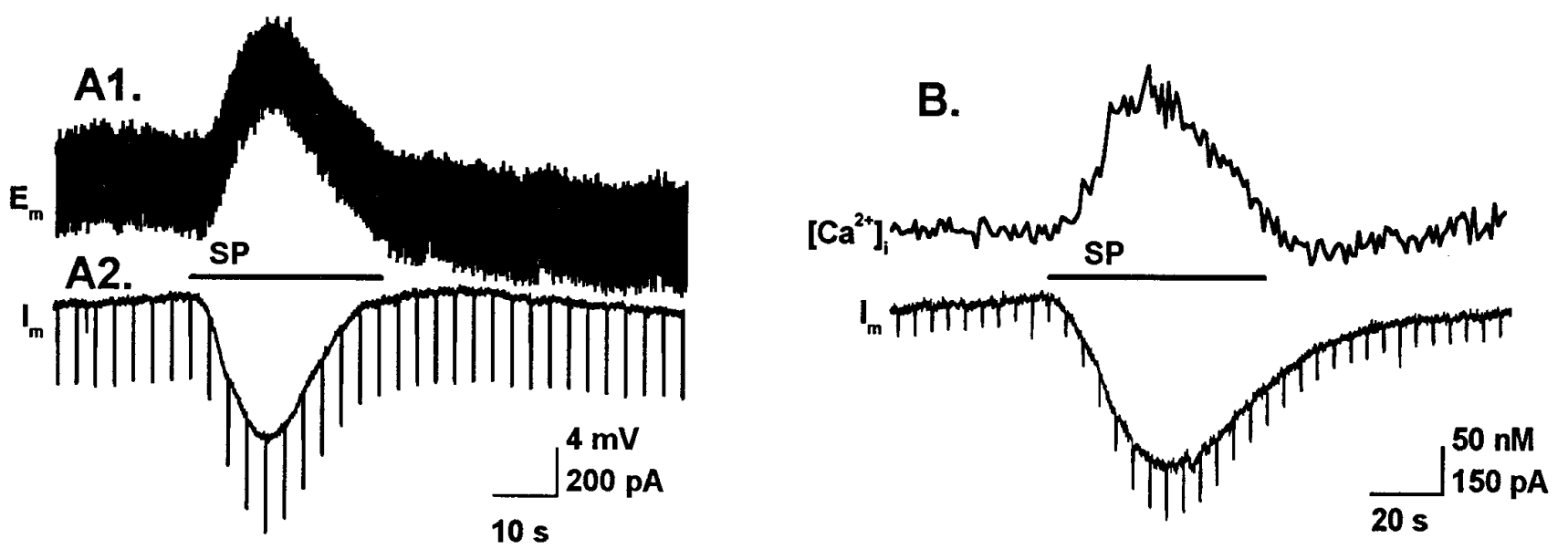

Figure 1. Responses produced by SP in intact and acutely isolated nodose neurons after antigen challenge. $A 1, A 2$, Neuronal membrane properties recorded $60 \mathrm{~min}$ after antigen challenge $(10 \mu \mathrm{g} / \mathrm{ml}$ OVA) of a nodose ganglion isolated from an actively immunized guinea pig. $A 1$, Depolarizing response produced by a $30 \mathrm{sec}$ application of $100 \mathrm{nM}$ SP (horizontal bar) recorded from a neuron in an intact ganglion. Resting potential was $-56 \mathrm{mV}$. The width of the trace reflects the magnitude of electrotonic voltage transients elicited by hyperpolarizing current pulses $(100 \mathrm{pA}, 200 \mathrm{msec}, 1.7 \mathrm{~Hz})$ to monitor the membrane input resistance $\left(R_{\text {in }}\right)$. SP produced a membrane depolarization that is accompanied by a decreased $R_{\text {in. }} . A 2$, Inward current in response to a $30 \mathrm{sec}$ application of $100 \mathrm{nM} \mathrm{SP}$, recorded in another nodose ganglion 65 min after antigen challenge. The neuron was voltage-clamped at $-62 \mathrm{mV}$. Downward deflections are hyperpolarizing voltage step commands $(-10 \mathrm{mV}, 100 \mathrm{msec}, 0.6 \mathrm{~Hz})$ to monitor membrane conductance $\left(G_{\mathrm{m}}\right)$. SP induces an inward current $(\sim 600 \mathrm{pA})$ and an increased $G_{\mathrm{m}}$. $B$, Simultaneous recording of changes in $\left[\mathrm{Ca}^{2+}\right]_{\mathrm{i}}$ and membrane current from an acutely isolated nodose ganglion neuron. A ganglion isolated from an immunized guinea pig was challenged with OVA and after 60 min enzymatically dissociated. The top and bottom records show the $\mathrm{Ca}^{2+}$ transient and inward current in response to a 60 sec application of $100 \mathrm{~nm}$ SP (horizontal bar) when the neuron was voltage-clamped to $-58 \mathrm{mV}$. The calcium transient peaks and returns to baseline before the inward current. The inward current $(\sim 550 \mathrm{pA})$ is accompanied by an increased $G_{\mathrm{m}}(117 \%$ over control $)$, as reflected by the larger size of the inward current steps evoked by hyperpolarizing voltage step commands $(-10 \mathrm{mV}, 300 \mathrm{msec}, 0.2 \mathrm{~Hz})$. In neurons from nonimmunized animals or before antigen challenge, SP application never produced changes in membrane potential or current $(n=28$, see text).

Data analysis. Data are expressed as mean \pm SEM. Student's twotailed $t$ test was used to assess significant differences between calculated means; $p<0.05$ was considered significant. Curve fitting and statistical analysis were performed using Sigmaplot and Sigmastat software (Jandel Scientific, San Rafael, CA). A semilogarithmic plot of the concentrationresponse relationships was iteratively fit using the four-parameter logistic equation:

$$
Y=\frac{(\max -\min )}{\left(1+\frac{x}{\mathrm{EC}_{50}}\right)^{b}}-\min ,
$$

where $Y$ is the response to $x$ concentration of SP or $\left[\beta-\mathrm{Ala}^{8}\right]$ neurokinin A $\left(\left[\beta-A l a^{8}\right] N K A\right)$, max and min are the maximum and minimum responses, $\mathrm{EC}_{50}$ is the $\mathrm{SP}$ or $\left[\beta-\mathrm{Ala}^{8}\right] \mathrm{NKA}$ concentration at half-maximum response, and $b$ is the Hill coefficient using the Levenberg-Marquardt nonlinear least squares algorithm (Sigmaplot).

\section{RESULTS}

\section{Characterization of the SP responses}

Absence of SP responses recorded in control nodose ganglion neurons

Recordings from 41 nodose neurons from 12 naive ganglia or 30 neurons from seven antigen-sensitized (but unchallenged) ganglia did not reveal measurable membrane potential $( \pm 1 \mathrm{mV})$ or membrane input resistance $( \pm 5 \mathrm{M} \Omega)$ changes after bath application of SP up to $1 \mu \mathrm{M}$. SP $(100 \mathrm{~nm}-10 \mu \mathrm{M})$ also did not elicit measurable membrane potential changes in acutely isolated nodose neurons $(n=28)$.

In contrast to these observations on vagal afferent neurons, the membrane properties of other sensory neurons in the guinea pig are clearly affected by SP. This peptide can, for example, depolarize trigeminal ganglion neurons (Spiegelman and Puil, 1990), and it has been reported to hyperpolarize cochlear outer hair cells (Kakehata et al., 1995). Moreover, sympathetic, parasympa- thetic, and myenteric neurons in the guinea pig are depolarized by tachykinins, including SP (Otsuka and Yoshioka, 1993). Thus, the unresponsive nature of nodose neurons appears to be an intrinsic property of these vagal afferents.

\section{SP responses recorded from nodose ganglion neurons after allergic inflammation}

After superfusion with the sensitizing antigen (chick OVA, 10 $\mu \mathrm{g} / \mathrm{ml}$ ), nodose neurons from actively sensitized guinea pigs revealed a histamine-mediated membrane depolarization $(\sim 6$ $\mathrm{mV}$ ) that persisted for $5 \mathrm{~min}$ (see Undem et al., 1993, their Fig. 1). This concentration of antigen is optimal for mediator release from mast cells (Undem et al., 1993). The sensitivity of nodose neurons to bath-applied SP was usually tested $>30$ min after antigen challenge to avoid overlap with the transient histamine response. In recordings from 82 of 99 neurons (83\%) in 30 ganglia, $100 \mathrm{~nm}$ SP produced a discernable membrane depolarization ( $\geq 2 \mathrm{mV}$; Figs. 1, 2). The peak depolarization averaged $6 \pm 0.3$ (range, $3-22) \mathrm{mV}(n=82)$ and was accompanied by a $21 \pm 8 \%$ decrease in membrane input resistance. SP also produced a depolarizing response in acutely dissociated neurons derived from antigenically challenged nodose ganglia. In $89 \%$ of isolated neurons, $100 \mathrm{~nm}$ SP produced a $12 \pm 0.9 \mathrm{mV}$ depolarizing response (range, 3-39 $\mathrm{mV} ; n=43$ ). The SP-induced depolarization was accompanied by a $27 \pm 2.7 \%$ (range, $5-76 \%, n=$ 44 of 50 neurons) decrease in membrane input resistance in $88 \%$ of the neurons. In the remaining neurons, there was either no change $(10 \%)$ or a slight increase $(2 \%)$ in membrane input resistance.

The mean depolarizing SP response recorded from neurons in intact ganglia was about one-half of that measured in acutely isolated neurons $(p<0.001)$. This discrepancy could reflect the 
differences in membrane input resistance recorded in intact $(47 \pm$ $6 \mathrm{M} \Omega ; n=108$ ) (Undem et al., 1993) versus acutely isolated neurons (93 $\pm 7 \mathrm{M} \Omega ; n=47)$. Alternatively, neutral endopeptidases present in the intact ganglia may be degrading SP. The basis for these differences was not pursued further in the current work.

SP-induced changes in membrane potential and membrane current recorded in intact and acutely dissociated neurons are shown in Figure 1. Superfusion of $100 \mathrm{~nm} \mathrm{SP}$, for $30 \mathrm{sec}$, evoked a membrane depolarization (or inward current) that appeared within a few seconds after SP reached the recording chamber, coincident with an increase in membrane conductance (Fig. $1 A 2, B)$. As illustrated in Figure $1 B$, similar inward currents could be recorded in acutely dissociated neurons superfused with SP. In isolated neurons, the population response to bath application of $100 \mathrm{~nm}$ SP recorded in voltage clamp averaged $688 \pm 95.2$ (range, 420-900) pA, accompanied by a $68 \pm 23.0 \%$ (range, $11-156 \%$ ) increase in membrane conductance $(n=6)$.

\section{Control experiments}

When ganglia removed from actively sensitized guinea pigs were challenged with $10 \mu \mathrm{g} / \mathrm{ml}$ human serum albumin (HSA; three ganglia) or $10 \mu \mathrm{g} / \mathrm{ml}$ bovine serum albumin (BSA; four ganglia) rather than the sensitizing antigen (OVA), none of the neurons tested with $100 \mathrm{~nm}$ SP revealed a measurable change in membrane potential or membrane input resistance (14 from HSA- and 16 from BSA-treated ganglia). Similarly, no measurable membrane potential changes were observed in 12 neurons (three ganglia) isolated from naive guinea pigs that were challenged with 10 $\mu \mathrm{g} / \mathrm{ml}$ OVA. Finally, we incubated nodose neurons isolated from control ganglia with $10 \mu \mathrm{g} / \mathrm{ml}$ OVA for 5-30 min. Application of $100 \mathrm{~nm}$ SP to these neurons $(n=5)$ did not produce measurable changes in membrane potential. Thus, the SP responses observed in ganglia removed from actively sensitized animals, after specific antigen challenge, are likely to arise as a consequence of a specific antigen-antibody interaction.

\section{Onset time and the longevity of the SP response}

To gain insight into the process underlying the unmasking of SP responses, we determined how rapidly after antigen challenge this effect occurs and how long it persists. The data shown in Figure $2 A$ depict the time course for induction of the SP response recorded in neurons from intact ganglia. At the earliest time point examined [immediately after the $15 \mathrm{~min}$ period of antigen (OVA) application; Fig. $2 A$, zero time point], only 1 of 11 neurons showed a measurable depolarization $(4 \mathrm{mV})$ in response to 100 nM SP. Fifteen minutes after OVA application, 2 of 10 neurons responded to SP ( 3 and $4 \mathrm{mV}$ ), and by $30 \mathrm{~min}, 10$ of 10 neurons responded [ $6 \pm 1.4$ (range, $4-10) \mathrm{mV}$ ]. The $30 \mathrm{~min}$ time point also reflects the time required to reach maximum effect. The magnitude of SP responses measured 1, 2, 4, and $8 \mathrm{hr}$ after antigen challenge were not significantly different from those recorded at 30 min $(p=0.741$; Fig. $2 A)$. Thus, the onset of unmasking SP responses follows a relatively rapid time course.

We next asked how long these SP responses persist. Because it is not feasible to maintain nodose neurons in the intact ganglia for long periods without incurring degenerative changes, we examined the longevity of the unmasked responses in dissociated neurons. Sensitized nodose ganglia were challenged with OVA in the usual manner and incubated for $60 \mathrm{~min}$ in Locke solution, and then the neurons were dissociated. Dissociated nodose neurons were maintained under sterile conditions and tested for responsiveness to SP over several days. The results shown in Figure $2 B$

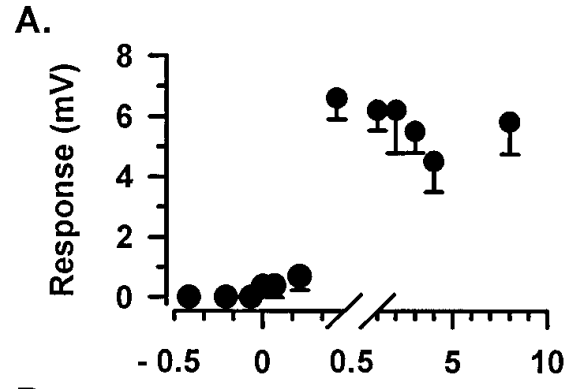

B.

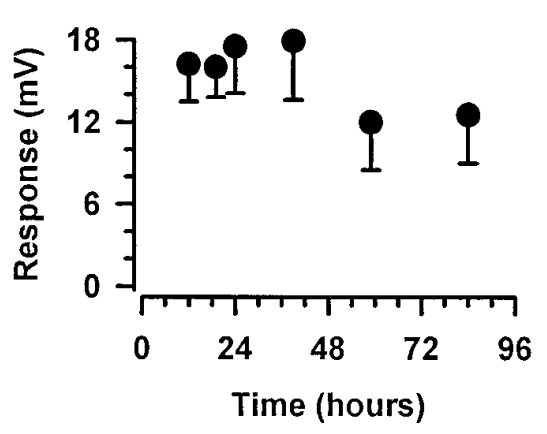

Figure 2. Time course of unmasking and longevity of the antigeninduced depolarizing SP response. $A$, Time course of SP responses recorded in neurons from intact nodose ganglia. Each data point represents the mean \pm SEM of 6-14 neurons. The 0 time point is immediately after a 5 min challenge of ganglia with the sensitizing antigen OVA $(10 \mu \mathrm{g} / \mathrm{ml})$. Within $30 \mathrm{~min}$ of challenge with OVA, SP responses are maximal. Eight $\mathrm{hr}$ after antigen challenge, the SP responses were not significantly diminished from the maximal responses recorded at $30 \mathrm{~min}(p=0.741)$. $B$, The persistence of the SP responses was evaluated in acutely isolated nodose neurons. Ganglia from immunized guinea pigs were antigenically challenged, and $60 \mathrm{~min}$ later neurons were isolated by enzymatic dissociation and incubated for varying periods. Responsiveness to SP persists for at least $3.5 \mathrm{~d}$. SP responses recorded from neurons $12 \mathrm{hr}$ after dissociation were not significantly different from those recorded in neurons $\geq 60 \mathrm{hr}$ after dissociation $(p=0.2885)$. The mean SP response recorded in acutely isolated neurons is significantly greater than the mean response recorded in neurons from intact ganglia. This difference is caused by the greater resting input resistance values of the isolated neurons (see text). Each data point represents the mean \pm SEM of three to nine neurons.

reveal that, once expressed, SP responses persist for at least $3.5 \mathrm{~d}$, the longest period studied. The average SP-induced depolarization recorded in neurons cultured for $\geq 2.5 \mathrm{~d}[12 \pm 2.2$ (range, $6-18) \mathrm{mV} ; n=5$ ] was not significantly different $(p=0.2885)$ from that recorded in neurons cultured for $12 \mathrm{hr}$ [16 \pm 2.7 (range, $10-25) \mathrm{mV} ; n=5]$. Neurons dissociated from control ganglia and maintained under similar culture conditions for $3 \mathrm{~d}$ did not show measurable SP responses. If these results with isolated neurons accurately reflect the longevity of unmasked SP responses in intact ganglia, then it appears that down regulation of the SP responses is a slow process.

\section{Pharmacology of the SP response}

Endogenous tachykinins (SP, neurokinin A, and neurokinin B) activate three distinct tachykinin receptors, designated NK-1, NK-2, and NK-3 (Maggi, 1995). We pharmacologically characterized the type of tachykinin receptor mediating the SP-induced depolarization by analyzing the effectiveness of selective tachykinin agonists and antagonists and by deriving $\mathrm{EC}_{50}$ values from concentration-response relations. As shown in Figure 3, application of $10 \mathrm{~nm}\left[\beta\right.$-Ala $\left.{ }^{8}\right] \mathrm{NKA}$, an NK-2-specific agonist, elicited a membrane depolarization accompanied by a decrease membrane 

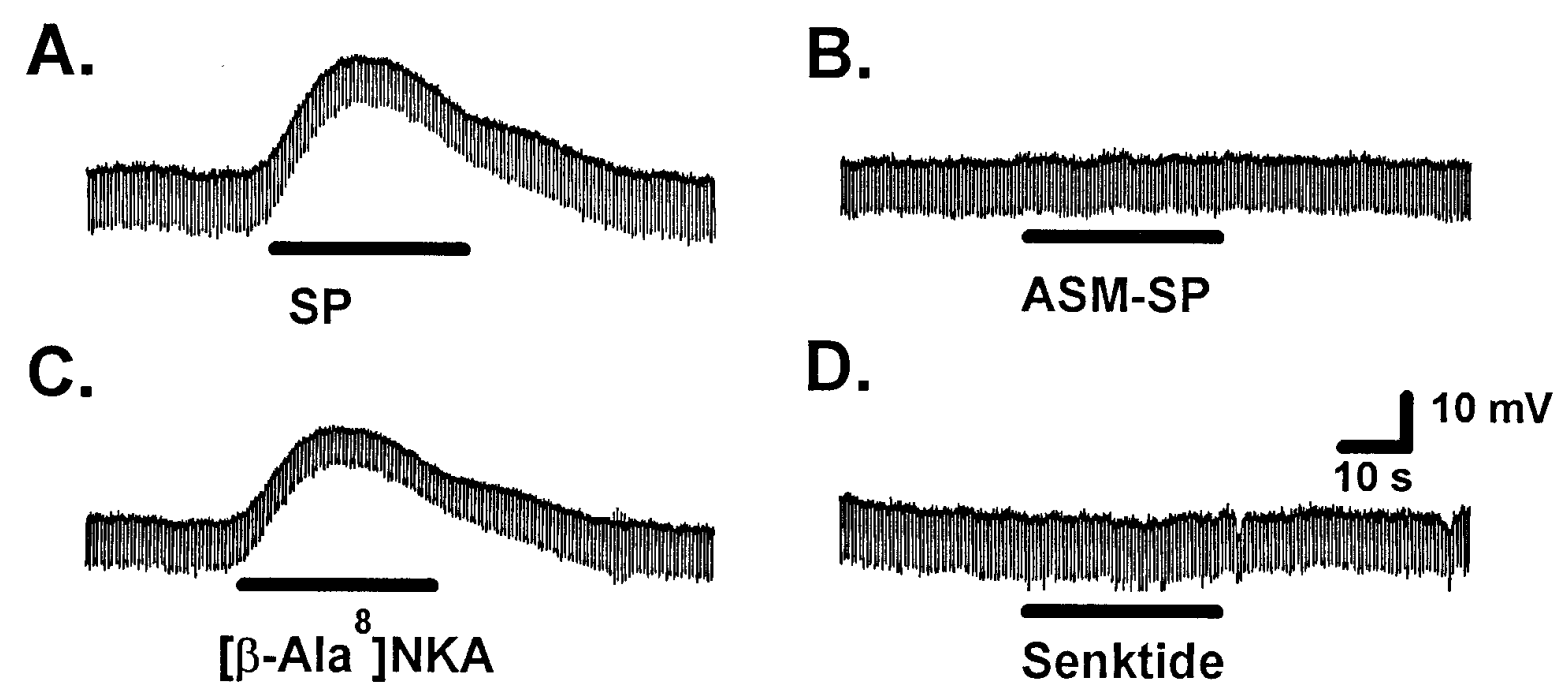

Figure 3. Effect of tachykinin receptor agonists on the membrane potential and resting input resistance of an acutely isolated neuron from a nodose ganglion challenged with the sensitizing antigen $(10 \mu \mathrm{g} / \mathrm{ml} \mathrm{OVA}) . A$, Current-clamp recording of the membrane depolarization in response to superfusion of SP $(100 \mathrm{nM})$. The membrane depolarization is associated with a decreased resting membrane resistance $\left(R_{\text {in }}\right)$, as reflected by the diminution of the hyperpolarizing electrotonic voltage transients elicited by transmembrane constant-current pulses $(-100 \mathrm{pA}, 200 \mathrm{msec}, 1.7 \mathrm{~Hz})$. Resting membrane potential is $-75 \mathrm{mV} ; R_{\mathrm{in}}$ is $100 \mathrm{M} \Omega$. The $30 \mathrm{sec}$ period of drug application is indicated by the horizontal bar. B, Application of a selective NK-1 receptor agonist, ASM-SP (100 nM), produces no discernable change in the membrane potential or $R_{\mathrm{in}}$. $C$, A selective NK-2 receptor agonist, $\left[\beta\right.$-Ala $\left.{ }^{8}\right]$ neurokinin A $(10 \mathrm{nM})$, mimics the SP response, producing a membrane depolarization with an associated decrease in $R_{\mathrm{in}} . D$, Senktide analog $(100 \mathrm{nM})$, a selective NK-3 receptor agonist, does not elicit a measurable change in membrane potential or $R_{\text {in. }}$. All responses were recorded in the same neuron.

input resistance similar to that produced by SP. In nine neurons, the average membrane depolarization was $11 \pm 1.2$ (range, 7-17) $\mathrm{mV}$. By contrast, bath application of $100 \mathrm{nM}$ ASM-SP $(n=5)$ or $100 \mathrm{nM}$ senktide analog $(n=3)$, selective NK-1 and NK-3 receptor agonists, respectively, produced no discernable $(<1$ $\mathrm{mV}$ ) membrane potential changes. Thus, from this profile of responses to tachykinin agonists, the unmasked tachykinin receptor appears to be an NK-2 subtype.

CP-99,994, SR48968, and SR142801 are selective nonpeptide antagonists acting at NK-1 (Snider et al., 1991), NK-2 (EmondsAlt et al., 1992), and NK-3 (Oury-Donat et al., 1995) receptors, respectively. CP-99,994 (100 nM; $n=4)$ and SR142801 (300 nM; $n=5$ ) produce no inhibition of the SP-mediated depolarization. Conversely, the SP- or $\left[\beta-\mathrm{Ala}^{8}\right] \mathrm{NKA}$-induced depolarization ( $n=5$ and 3 , respectively) or inward current ( $n=3$ and 2, respectively) is completely abolished in the presence of $50 \mathrm{nM}$ SR48968. An example of the antagonistic effects of SR48968 is illustrated in Figure 4. These results with tachykinin receptor antagonists, along with those with receptor agonists described above, strongly indicate that allergen-induced inflammation results in the unmasking of functional tachykinin NK-2 receptors.

\section{Concentration-response relation to $S P$}

The concentration-response relationships for SP and [ $\beta$ Ala ${ }^{8}$ NKA were examined by voltage clamping acutely isolated nodose neurons near their resting potential $(-56 \mathrm{mV})$ and plotting the relation between different peptide concentrations and the peak amplitude of the inward currents. Normalization of inward currents was not necessary because of the reproducibility of responses from neuron to neuron. SP produced a concentrationdependent increase in inward current that saturates at $1 \mu \mathrm{M}$ with a peak current amplitude of $1.1 \mathrm{nA}$ (Fig. 5). [ $\beta$-Ala $\left.{ }^{8}\right] \mathrm{NKA}$ also produced a concentration-dependent increase in inward current that saturated at $300 \mathrm{~nm}$ with a peak current amplitude of $1.6 \mathrm{nA}$.
A semilogarithmic plot of peak inward current amplitude versus SP or $\left[\beta-\right.$ Ala $\left.^{8}\right]$ NKA concentration was well fit $\left(\chi^{2}=0.002\right.$ and 0.003 , respectively) by a sigmoidal relation that varied over 2 orders of magnitude (Fig. 5). The $\mathrm{EC}_{50}$ for the SP response was $78 \mathrm{~nm}$ with a Hill coefficient of 1.1 ; the $\mathrm{EC}_{50}$ of the $\left[\beta\right.$-Ala $\left.{ }^{8}\right] \mathrm{NKA}$ response was $33 \mathrm{~nm}$ with a Hill coefficient of 0.6. The increased potency and efficacy of $\left[\beta-\mathrm{Ala}^{8}\right] \mathrm{NKA}$ over SP further supports our contention that tachykinin NK-2 receptors are unmasked after an allergic inflammatory reaction in nodose ganglia.

\section{Characterization of the tachykinin responses \\ Changes in intracellular calcium}

Activation of tachykinin receptors can produce a G-proteinmediated elevation of $\left[\mathrm{Ca}^{2+}\right]_{i}$ (Otsuka and Yoshioka, 1993). To test whether unmasked tachykinin receptors are coupled to changes in $\left[\mathrm{Ca}^{2+}\right]_{i}$, we measured levels of $\left[\mathrm{Ca}^{2+}\right]_{i}$ using fura-2, a ratiometric calcium indicator. In acutely isolated nodose neurons from allergen-challenged ganglia, the baseline level of $\left[\mathrm{Ca}^{2+}\right]_{\mathrm{i}}$ was $79 \pm 12.5$ (range, $24-185) \mathrm{nm}(n=13)$. After application of SP (100 nM for $1 \mathrm{~min}),\left[\mathrm{Ca}^{2+}\right]_{\mathrm{i}}$ increased twofold over baseline values $[\Delta=183 \pm 46.9$ (range, $68-500) \mathrm{nm} ; n=11$; Fig. $1 B]$. As was the case for the SP-induced depolarization or inward current, the SP-induced rise in $\left[\mathrm{Ca}^{2+}\right]_{\mathrm{i}}\left(\Delta \mathrm{Ca}_{\mathrm{t}}\right)$ was also completely blocked by the selective NK-2 receptor antagonist SR48968 (100 nм; $n=3$; Fig. $6 B$ ).

\section{Comparisons between time course of the SP current and the $\Delta C a_{t}$}

Figure $1 B$ shows the temporal characteristics of the SP-induced inward current and the $\Delta \mathrm{Ca}_{\mathrm{t}}$ recorded in a neuron voltageclamped to $-58 \mathrm{mV}$. Because the neuron was voltage-clamped near its resting potential, the observed $\Delta \mathrm{Ca}_{\mathrm{t}}$ cannot be attributed 

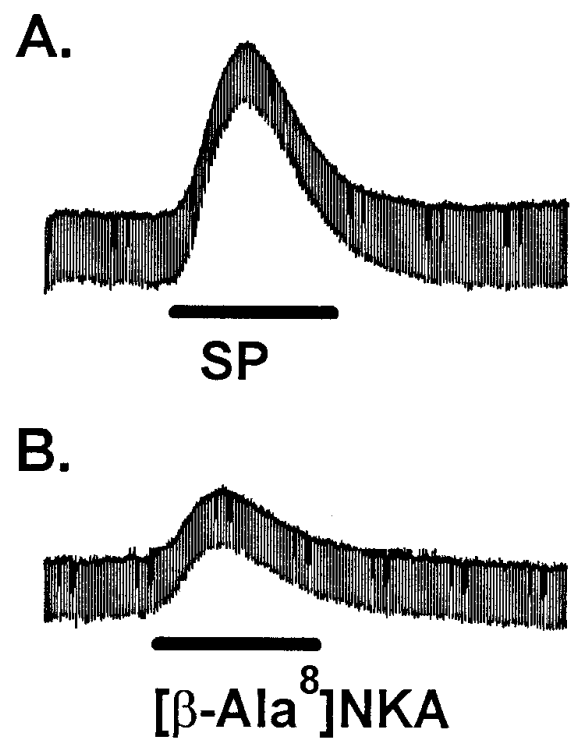
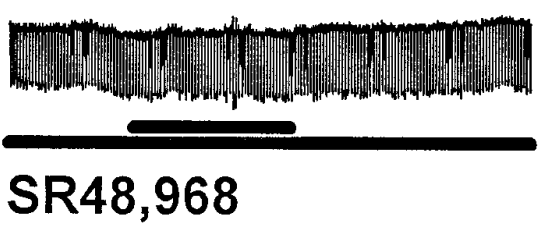

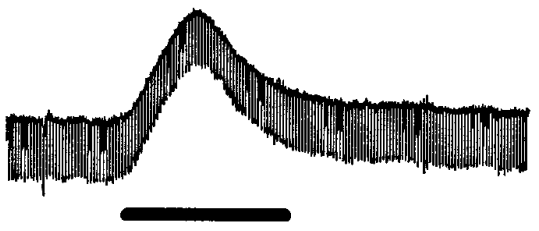

$10 \mathrm{mV}$

$20 \mathrm{~s}$
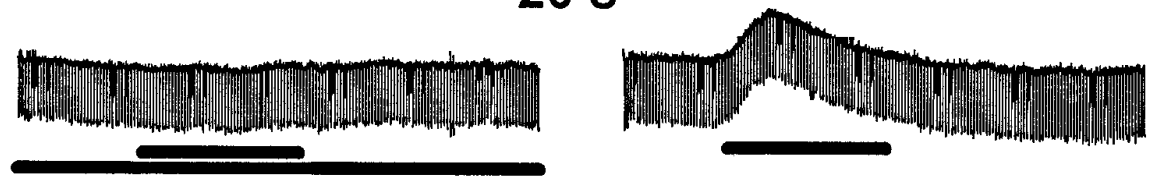

\section{SR48,968}
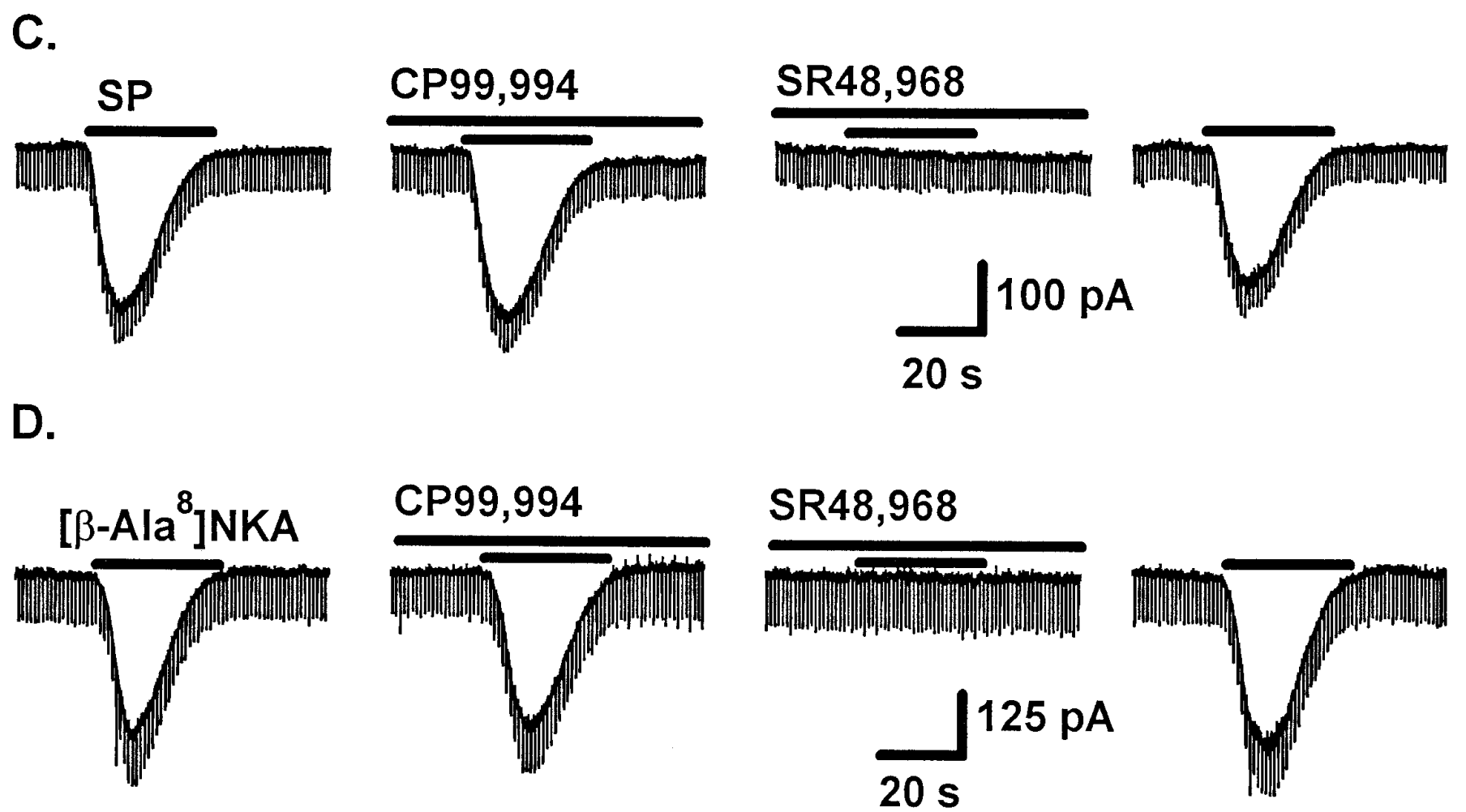

Figure 4. Effects of selective tachykinin receptor antagonists on SP- and $\left[\beta-\mathrm{Ala}^{8}\right] \mathrm{NKA}$-induced membrane depolarizations or inward currents elicited subsequent to antigen challenge. $A$, A $30 \mathrm{sec}$ application of SP $(100 \mathrm{nM})$ produces a membrane depolarization and a decrease in resting membrane resistance $\left(R_{\text {in }}\right)$ in an acutely isolated nodose neuron (left trace). Downward deflections are electronic voltage transients produced by $-100 \mathrm{pA}$ pulses, $200 \mathrm{msec}, 1.7$ $\mathrm{Hz}$ (see Fig. 1A). Middle trace, Application of SR48968 (50 nM), a specific NK-2 receptor antagonist, completely blocked the SP response (top horizontal bar). Right trace, The effect of SR48968 was reversible. After a 5 min wash in Locke solution, a subsequent application of SP elicited a membrane depolarization and decreased $R_{\mathrm{in}} \cdot B$, A $30 \mathrm{sec}$ application of $\left[\beta-\mathrm{Ala}^{8}\right] \mathrm{NKA}(10 \mathrm{nM})$, a selective NK-2 agonist, also induced a membrane depolarization (left trace) that was completely blocked by $50 \mathrm{~nm}$ SR48968 (middle trace). The antagonist action of SR48968 was almost reversible after superfusion with drug-free Locke solution (right trace). Traces in $A$ and $B$ were recorded from the same nodose neuron. The resting membrane potential was $-60 \mathrm{mV}$, and $R_{\text {in }}$ was $120 \mathrm{M} \Omega$. $C$, In another neuron, a $30 \mathrm{sec}$ application of SP (100 nM) produces an inward current. Downward deflections are current responses to - $10 \mathrm{mV}, 200 \mathrm{msec}$ voltage step commands delivered at $1 \mathrm{~Hz}$. In this particular neuron, SP produced a slight decrease in membrane conductance. The SP-induced inward current is unaffected by CP99,994 (100 nM), a specific NK-1 receptor antagonist, but subsequent application of SR48968 (100 nM) blocks the SP response. After a $10 \mathrm{~min}$ wash with drug-free Locke solution, the SP-induced inward current returns to near control values. The holding potential was $-57 \mathrm{mV}$. $D$, A $30 \mathrm{sec}$ application of $\left[\beta-\mathrm{Ala}^{8}\right] \mathrm{NKA}(10 \mathrm{nM})$ also induced an inward current. In this neuron, the inward current was not associated with a change in membrane conductance; downward deflections are elicited by hyperpolarizing voltage step commands $(-10 \mathrm{mV}, 200 \mathrm{msec}, 1 \mathrm{~Hz})$. The inward current is unaffected by CP99,994 but completely and reversibly blocked by SR48968. The holding potential was $-70 \mathrm{mV}$. Unlabeled horizontal bars indicate SP or $\left[\beta-\mathrm{Ala}^{8}\right]$ NKA application. All neurons were from antigen-challenged nodose ganglia and were held in culture for $8-14 \mathrm{hr}$. 


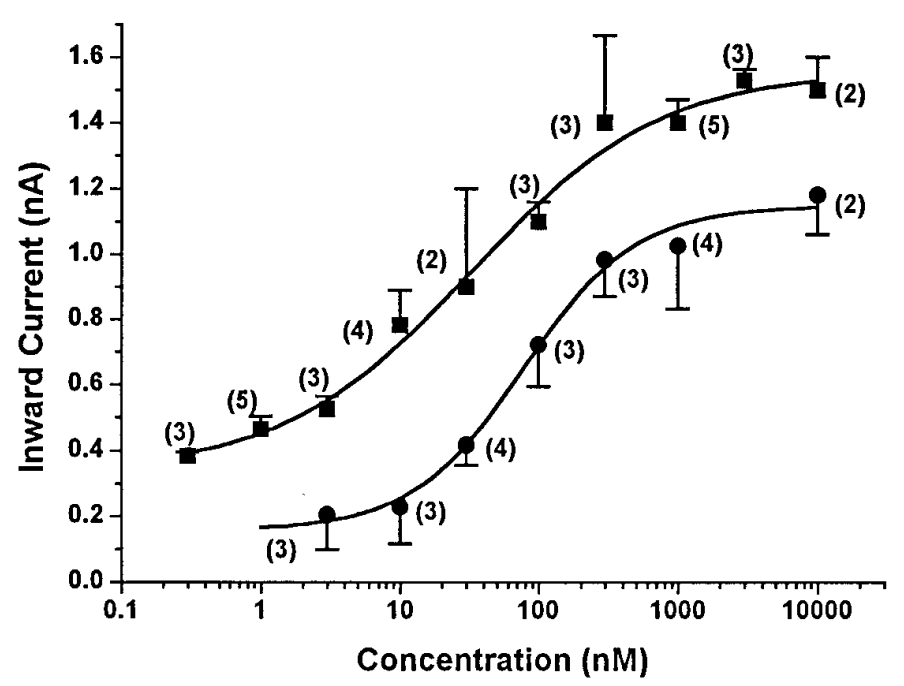

Figure 5. Concentration-response relation for SP- and $\left[\beta-\mathrm{Ala}^{8}\right] \mathrm{NKA}$ induced inward currents recorded in neurons isolated from antigenchallenged nodose ganglia. Semilogarithmic plot of the concentrationresponse relations for SP (circles) and for $\left[\beta-\mathrm{Ala}^{8}\right] \mathrm{NKA}$ (squares). Each data point represents the mean \pm SEM of the number of neurons indicated in parentheses next to each data point. The continuous lines represent logistic fits to the data for each agonist $\left(\chi^{2}=0.002\right.$ and 0.003 for SP and $\left[\beta-\mathrm{Ala}^{8}\right] \mathrm{NKA}$, respectively). The $\mathrm{EC}_{50}$ for the SP-induced inward current was $78 \mathrm{~nm}$ with a Hill coefficient of 1.1 ; the $\mathrm{EC}_{50}$ for the $[\beta$ Ala $\left.{ }^{8}\right]$ NKA-induced inward current was $33 \mathrm{nM}$, with a Hill coefficient of 0.6 . Each neuron was voltage-clamped to $-56 \mathrm{mV}$ and subjected to a 30 sec application of varying concentrations of SP or $\left[\beta-\mathrm{Ala}^{8}\right] \mathrm{NKA}$.

to $\mathrm{Ca}^{2+}$ influx via voltage-sensitive calcium channels. The $\Delta \mathrm{Ca}_{\mathrm{t}}$ reaches a maximum in $29 \pm 2.2$ (range, 19-35) sec $(n=7)$, whereas the inward current exhibits a more protracted time to peak amplitude, $47 \pm 6.5$ (range, $25-65) \sec (n=6 ; p=0.010)$. Additionally, the duration of the $\Delta \mathrm{Ca}_{\mathrm{t}}[72 \pm 5.7$ (range, 52-100) sec; $n=7$ ] was nearly one-half that of the inward current produced by SP $[113 \pm 14.3$ (range, 63-145) sec; $n=6 ; p=$ 0.008]. It should be noted that quantitative kinetic comparisons between these two variables are, unfortunately, subject to some uncertainty, because the time course of the $\Delta \mathrm{Ca}_{\mathrm{t}}$ reflects global changes in $\left[\mathrm{Ca}^{2+}\right]_{i}$, while the kinetics of the inward current is determined by events at the plasma membrane.

The discordance between the kinetics of the SP-induced $\Delta \mathrm{Ca}_{\mathrm{t}}$ and the inward current suggests that the $\Delta \mathrm{Ca}_{\mathrm{t}}$ is not attributable to calcium influx but rather to release from intracellular stores. We tested this conjecture by examining the effects of intracellular calcium chelation on the SP-induced $\Delta \mathrm{Ca}_{\mathrm{t}}$ and depolarization.

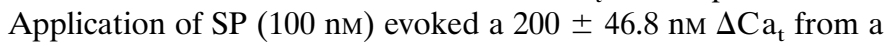
baseline of $69 \pm 27.2 \mathrm{nM}(n=3)$. After superfusion with $10 \mu \mathrm{M}$ BAPTA/AM, the $\Delta \mathrm{Ca}_{\mathrm{t}}$ was blocked $100 \%$ within $11 \pm 2.2 \mathrm{~min}$ (Fig. $6 C$ ). In four additional neurons, $100 \mathrm{~nm}$ SP produced a $20 \pm$ $2.9 \mathrm{mV}$ membrane depolarization. The resting input resistance decreased from $59 \pm 9.6$ to $30 \pm 6.8 \mathrm{M} \Omega$. Subsequent incubation with $10 \mu \mathrm{M}$ BAPTA/AM for $15 \mathrm{~min}$ completely blocked the SP-induced depolarization in all four neurons (Fig. 6D). These results support the contention that the SP-induced $\Delta \mathrm{Ca}_{\mathrm{t}}$ is necessary for membrane depolarization. Although it is likely that the major component of the $\Delta \mathrm{Ca}_{\mathrm{t}}$ is released from intracellular stores, the data do not eliminate the role of a $\mathrm{Ca}^{2+}$ influx component.

\section{Role of protein synthesis in unmasking of the tachykinin responses}

To test whether protein synthesis contributes to expression of tachykinin responses, nodose ganglia were incubated in Locke solution containing $100 \mu \mathrm{g} / \mathrm{ml}$ cycloheximide for $60 \mathrm{~min}$ and then challenged with antigen in the presence of cycloheximide. Under these conditions protein synthesis in guinea pig nodose ganglia was inhibited by $96 \%$ (see Materials and Methods). In 31 neurons from three ganglia treated with $100 \mu \mathrm{g} / \mathrm{ml}$ cycloheximide, SP (100 $\mathrm{nm}$ ) depolarized the membrane potential by $7.5 \pm 0.8$ (range, 2-21) $\mathrm{mV}$, a value that was not significantly different from depolarizing responses $[7.1 \pm 0.8$ (range, $2-24) \mathrm{mV} ; n=30]$ recorded in three contralateral control ganglia $(p=0.702)$. Two additional ganglia were incubated for 30 min with a Locke solution containing $100 \mu \mathrm{g} / \mathrm{ml}$ puromycin and subsequently challenged with antigen. Unmasked SP responses were also observed in neurons from these ganglia. These results indicate that new protein synthesis is not required for the unmasking of tachykinin responses after allergen-induced inflammation.

\section{Temperature dependence of the tachykinin response}

All of the studies described thus far were conducted at physiological temperature $\left(35-37^{\circ} \mathrm{C}\right)$. We tested the effects of lowering temperature on the SP and $\left[\beta-\mathrm{Ala}^{8}\right] \mathrm{NKA}$ responses by superfusing ganglia or isolated somata with room temperature $\left(22-24^{\circ} \mathrm{C}\right)$ Locke solution, after ganglia had been challenged with antigen at $37^{\circ} \mathrm{C}$. Application of tachykinin $(100 \mathrm{~nm})$ never evoked a measurable response in either dissociated neurons or neurons from intact ganglia ( $n=10$ for each group) when the neurons were superfused with room temperature Locke solution. The data shown in Figure 7 illustrate the effect of changing temperature on a SP response recorded in a dissociated nodose neuron. At $35.5^{\circ} \mathrm{C}$, SP elicited an $18 \mathrm{mV}$ depolarization. Lowering the temperature to $24.1^{\circ} \mathrm{C}$ resulted in a complete abolition of the SP response. After returning to $35.5^{\circ} \mathrm{C}$, application of SP produced a $12 \mathrm{mV}$ depolarizing response. The temperature sensitivity of the tachykinin response likely reflects involvement of a metabolically labile second messenger(s). An analogous temperature dependence has been reported for the depolarizing actions of angiotensin II in rat nodose ganglia (Widdop et al., 1990).

\section{Role of inflammatory mediators}

Assuming the mediator(s) responsible for unmasking functional $\mathrm{NK}-2$ receptors is directly derived from mast cells, there is no lack of candidate mediators. Mast cells secrete a plethora of granular (preformed) and newly synthesized mediators, including biogenic amines, proteases, cytokines, and a variety of lipid mediators, most notably prostanoids and leukotrienes (Theoharides, 1996). We have begun testing whether some of the most well characterized mast cell autacoids are involved in induction of this response. Ganglia were incubated in Locke solution containing a mixture of histamine $\mathrm{H} 1$ (pyrilamine, $1 \mu \mathrm{M}$ ), H2, and $\mathrm{H} 3$ (burimamide, $50 \mu \mathrm{M}$ ) receptor antagonists, at $\sim 100 \times$ their $K_{\mathrm{d}}$ values, during challenge with the sensitizing antigen; at $50 \mu \mathrm{M}$ burimamide inhibits both $\mathrm{H} 2$ and $\mathrm{H} 3$ histamine receptors (Christian et al., 1989, and references therein). Dissociated neurons were prepared from these ganglia after $60 \mathrm{~min}$. In histamine antagonist-treated neurons, SP elicited a $14 \pm 3.0 \mathrm{mV}$ depolarization $(n=13$ neurons, three ganglia) that was not significantly different ( $p=$ $0.492)$ from control values $(17 \pm 2.5 \mathrm{mV} ; n=9)$ recorded in neurons isolated from contralateral ganglia. Similar results were obtained with neurons from ganglia treated with a cyclooxygen- 


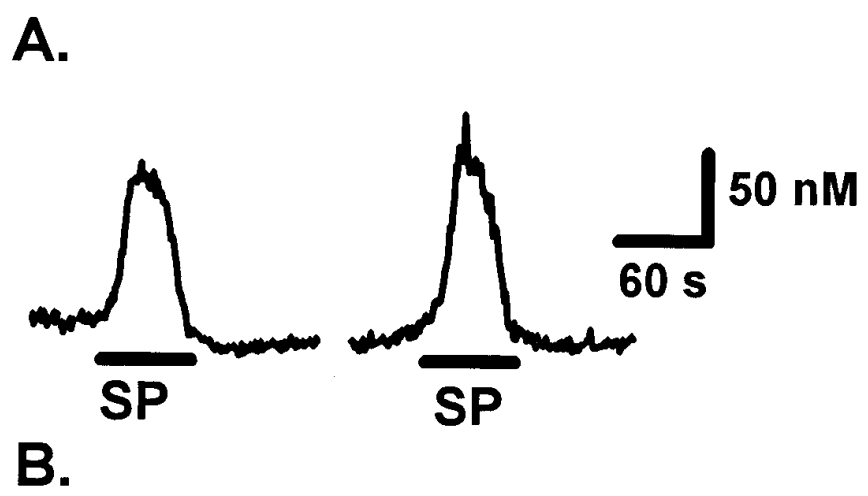

Figure 6. Effect of an NK-2 selective antagonist and intracellular calcium chelation on the SPinduced changes in $\left[\mathrm{Ca}^{2+}\right]_{i}$ (calcium transient) and membrane potential recorded in neurons isolated from antigen-challenged nodose ganglia. $A$, Multiple applications of $100 \mathrm{~nm}$ SP for $60 \mathrm{sec}$ elicit reproducible elevations of $\left[\mathrm{Ca}^{2+}\right]_{\mathrm{i}}$. Similar results were observed in six additional neurons. $B$, SP application in a second neuron elicits a calcium transient that can be completely abolished by $50 \mathrm{nM}$ SR48968, a specific NK-2 receptor antagonist. $C$, A SP-induced calcium transient recorded in a third neuron is blocked within $7 \mathrm{~min}$ of switching to a superfusate containing $10 \mu \mathrm{M}$ BAPTA/AM. $D$, SPinduced membrane depolarization and associated decrease in membrane input resistance $\left(R_{\text {in }}\right)$ monitored by the magnitude of the electrotonic voltage transients evoked by $-100 \mathrm{pA}, 300 \mathrm{msec}$ current steps $(0.2 \mathrm{~Hz})$. Superfusion of $10 \mu \mathrm{M}$ BAPTA/AM for $15 \mathrm{~min}$ blocks the response to a subsequent application of SP. Resting potential was $-67 \mathrm{mV}$; $R_{\text {in }}$ was $50 \mathrm{M} \Omega$. Note increases in $\mathrm{R}_{\text {in }}$ with BAPTA/AM application; it occurs in half of the neurons.
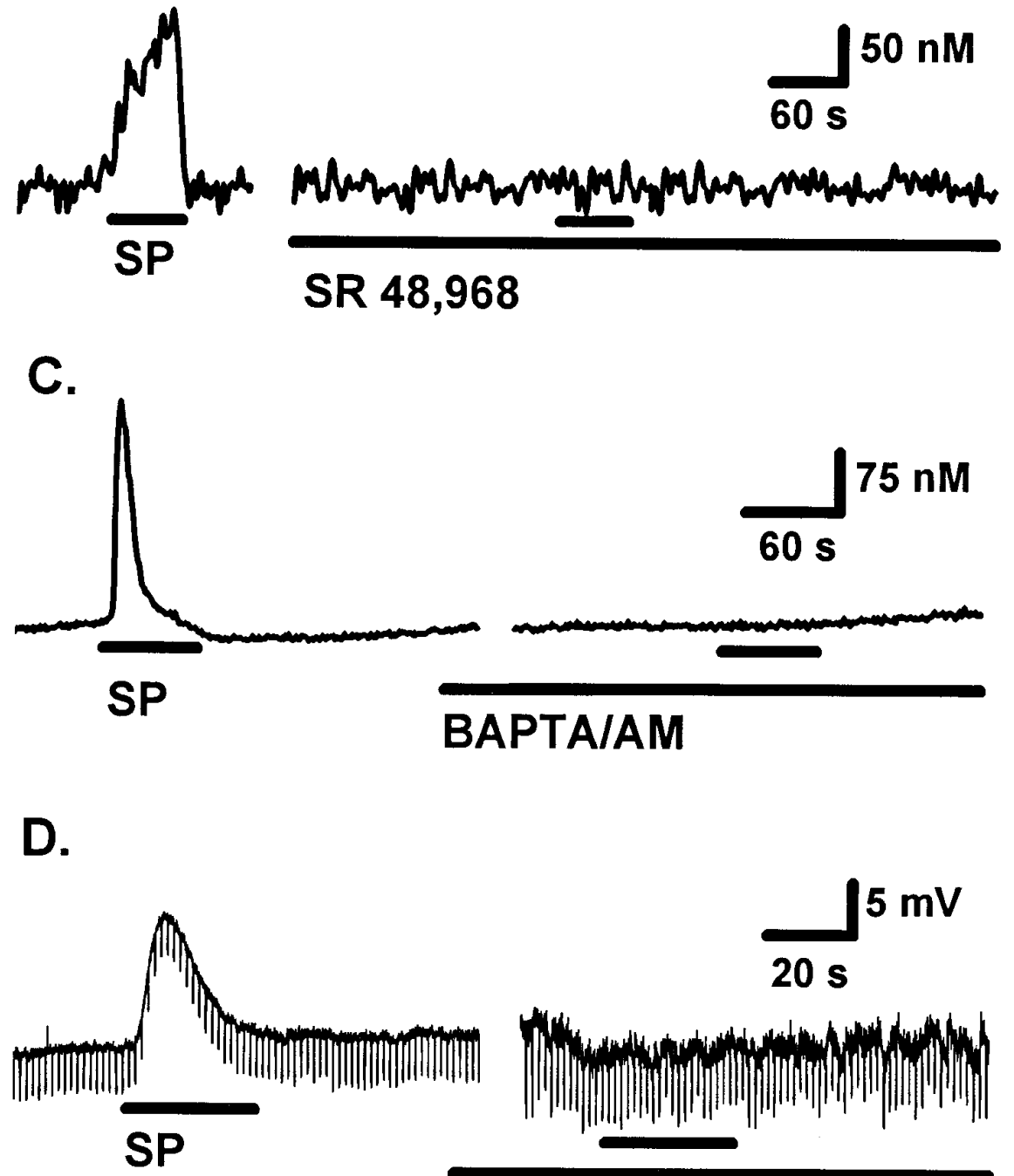

BAPTA/AM

ase inhibitor that prevents prostanoid formation, indomethacin ( 3 $\mu \mathrm{M} ; n=5$ ), or with a 5'-lipoxygenase inhibitor (Ford-Hutchinson et al., 1994) that prevents peptidoleukotriene formation, ZD2138 (3 $\mu \mathrm{M} ; n=10)$. There were no significant differences in the magnitude of the SP responses recorded from treated versus contralateral control neurons.

\section{DISCUSSION}

Our principal finding is that allergen-induced inflammation evokes a long-lasting (days) unmasking of functional NK-2 re- ceptors in vagal afferent somata. Immunological activation of mast cells resident to vagal ganglia releases numerous preformed and newly synthesized inflammatory mediators. These mediators evoke a constellation of excitability changes, including membrane depolarization, increases and decreases in resting membrane conductances, inhibition of a time- and voltage-dependent inward rectifying current, and block of an $\mathrm{AHP}_{\text {slow }}$, a membrane property responsible for spike frequency adaptation in nodose neurons (Weinreich and Wonderlin, 1987; Undem and Weinreich, 1993). 

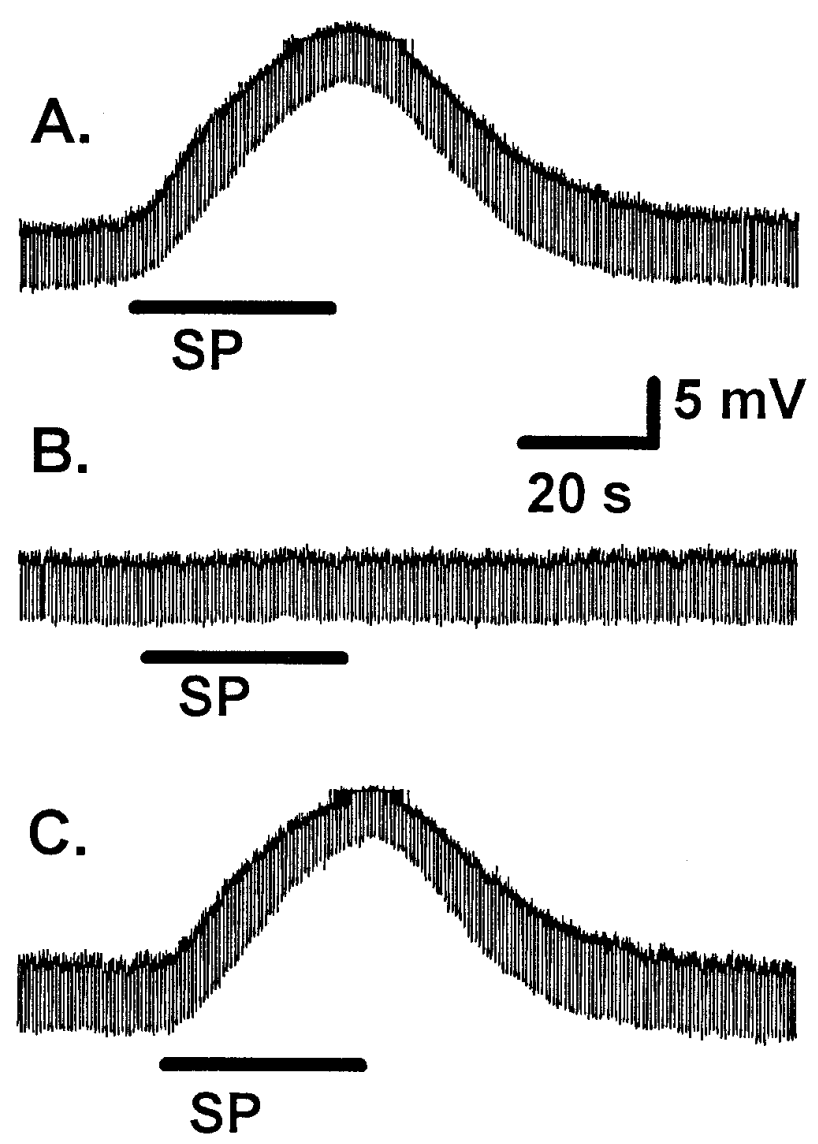

Figure 7. Effect of temperature on unmasked SP responses recorded in a neuron isolated from an antigen-challenged nodose ganglion. $A$, A 30 sec application of SP elicits a depolarizing response recorded at $35.5^{\circ} \mathrm{C} . B$, At $24.1^{\circ} \mathrm{C}$, the SP response is abolished. $C$, After returning to $35.5^{\circ} \mathrm{C}$, the SP response returns to near control values. Resting membrane potential and resting input resistance were $-64 \mathrm{mV}$ and $50 \mathrm{M} \Omega$, respectively. Downward deflections are electronic voltage transients produced by -100 pA $(200 \mathrm{msec}, 1.7 \mathrm{~Hz})$ current steps 15 . Fifteen minute intervals occurred between SP applications.

In contrast to those reported here, these immunomodulatory effects were transient, lasting only 3-15 min. The persistent nature of the unmasked tachykinin responses after antigen challenge resembles more closely the long-term increase in synaptic efficacy recorded in sympathetic ganglia, after specific antigen challenge of ganglia removed from actively (Weinreich et al., 1995) or passively (Albuquerque et al., 1996) sensitized guinea pigs.

Histological, biochemical, and pharmacological studies (Greene et al., 1988; Christian et al., 1989; Undem et al., 1993) have shown that immunological activation of ganglionic mast cells and the ensuing release of their inflammatory mediators is an integral step in the development of both transient and persistent neural changes. Because the present results with nodose ganglia were obtained using the same experimental paradigm of immunological stimulation of mast cells, the unmasking of NK-2 receptors is also dependent on mast cell activation. Whether the signal molecule(s) responsible for unmasking NK-2 receptors is exclusively mast cell-derived remains unknown at present. It may be that mast cell mediators affect nodose neurons indirectly by inducing the release of signal molecules from macrophages, endothelial cells, glial cells, or other cell types residing within the nodose ganglion.

\section{Tachykinin-induced depolarization and increase in $\left[\mathrm{Ca}^{2+}\right]_{i}$}

Both the $\left[\beta-\mathrm{Ala}^{8}\right] \mathrm{NKA}$ - and SP-induced depolarizations (or inward currents) were associated with an increase in membrane conductance and had an estimated reversal potential of $-1 \pm 3.2$ $\mathrm{mV}(n=3$, SP response; D. Weinreich, K. A. Moore, and G. E. Taylor, unpublished observations). Taken together, these results suggest that the unmasked tachykinin receptors may activate a nonselective cation conductance. Tachykinin-induced depolarizing responses can be produced by a variety of ionic mechanisms, including inhibition of outward $\mathrm{K}^{+}$currents, activation of inward $\mathrm{Na}^{+}$currents, and activation of an inward nonselective cation current (Nakajima and Nakajima, 1994). Our results resemble those recorded in cultured rat sensory neurons, in which ion permeability studies revealed tachykinin-induced nonselective cation currents (Inoue et al., 1995).

All three subtypes of tachykinin receptors can be coupled to inositol 1,4,5-triphosphate $\left(\mathrm{IP}_{3}\right)$ production through $\mathrm{G}$-proteinmediated inositol phospholipid hydrolysis. This second messenger triggers the release of calcium from intracellular stores (Otsuka and Yoshioka, 1993). We observed that a transient rise in $\left[\mathrm{Ca}^{2+}\right]_{\mathrm{i}}\left(\Delta \mathrm{Ca}_{\mathrm{t}}\right)$ always accompanied the tachykinin-induced inward currents. Chelation of intracellular $\mathrm{Ca}^{2+}$ with BAPTA/AM resulted in a block of both $\Delta \mathrm{Ca}_{\mathrm{t}}$ and the inward current. However, the time to peak and duration of the $\Delta \mathrm{Ca}_{\mathrm{t}}$ was always shorter (by approximately twofold) than the corresponding inward current. Together, these data imply that (1) an internal $\mathrm{Ca}^{2+}$ pool, most likely the $\mathrm{IP}_{3}$ store, is necessary for the activation of the inward current; and (2) elevation of intracellular $\mathrm{Ca}^{2+}$ alone is not sufficient to maintain the inward current. The role of $\mathrm{IP}_{3}$ remains to be explored.

\section{Pharmacological characterization of the unmasked tachykinin response}

The endogenous tachykinins SP, NKA, and NKB show preference for the NK-1, NK-2, and NK-3 tachykinin receptor subtypes, respectively (Maggi, 1995). The tachykinin receptor characterized in this study most closely resembles an NK-2 receptor. The response was mimicked by the NK-2 receptor selective agonist $\left[\beta-\mathrm{Ala}^{8}\right] \mathrm{NKA}(10 \mathrm{~nm})$ but not by agonists specific for the NK-1 or NK-3 receptors, $\left[\operatorname{Arg}^{6}, \operatorname{Sar}^{9}, \operatorname{Met}\left(\mathrm{O}_{2}\right)^{11}\right] \mathrm{SP}(6-11)$ and senktide analog, respectively. Furthermore, SR48968 (50 nM), an NK-2 selective antagonist (Emonds-Alt et al., 1992), abolished the response to either SP or $\left[\beta-\mathrm{Ala}^{8}\right] \mathrm{NKA}$, although NK-1 and NK-2 selective antagonists CP-99,994 and SR142801, respectively, did not inhibit the responses to SP or $\left[\beta-\mathrm{Ala}^{8}\right] \mathrm{NKA}$.

Further support for the view that specific tachykinin receptors are expressed was obtained from concentration-response relations. The concentration-inward current relations for SP and $\left[\beta\right.$-Ala $\left.{ }^{8}\right]$ NKA were sigmoidal log concentration-response curves that saturated over 2 orders of magnitude with $\mathrm{EC}_{50}$ values of 78 and $33 \mathrm{nM}$, respectively. In general, NKA is a more potent activator of $\mathrm{NK}-2$ receptors than is $\mathrm{SP}$. Although $\mathrm{EC}_{50}$ values for $\mathrm{NK}-2$ receptors in guinea pig nervous tissues are currently not available, we expected a greater than a twofold potency difference between SP and $\left[\beta-\mathrm{Ala}^{8}\right] \mathrm{NKA}$. Nonetheless, it is recognized that the NK-2 receptor displays wide interspecies and intraspecies differences with respect to binding properties and antagonist affinity (Maggi, 1995). 


\section{Mechanisms by which NK2 receptor-mediated responses are unmasked}

In the absence of protein synthesis, tachykinin responses are unmasked relatively rapidly (within $30 \mathrm{~min}$ ), suggesting that receptor expression is dependent on post-translational processes. At least two general mechanisms might be considered. First, receptor exocytosis may underlie the unmasking of NKA responses. Preexisting, fully functional NK-2 receptors could be housed in cytoplasmic vesicles close to the plasma membrane and inserted into the plasma membrane after antigen challenge. Although there is substantial data indicating that after peptide binding tachykinin receptors undergo rapid internalization (in minutes) into endosomal vesicles (Mantyh et al., 1995; Garland et al., 1996), less information is available about the mechanisms controlling the return of receptor-containing vesicles back to the plasma membrane.

A related possibility is that tachykinin receptors in nodose neurons reside in cytoplasmic vesicles and are shuttled to the plasma membrane in a manner analogous to water channels (aquaporins) in epithelial cells (Brown et al., 1995). Activation of the exocytotic pathway and membrane expression of aquaporins can occur within min after vasopressin stimulation. In these systems, in contrast to our observations with the NK-2 responses, when the initiating stimuli (vasopressin) is removed, the aquaporins are rapidly internalized.

An alternative explanation for the unmasking of NK-2 receptors is that they already exist in the plasma membrane but are uncoupled from their effector targets, second messengers, or ion channels, until an inflammatory mediator(s) induces recoupling. To date, all members of the tachykinin receptor family have been linked to their effectors via G-proteins, and the affinity state of tachykinin receptors is influenced by G-protein coupling (Otsuka and Yoshioka, 1993). The G-protein-coupled receptor represents a high-affinity state, while the uncoupled receptor represents a low-affinity state (McLean and Lowe, 1994). Assuming that the $\mathrm{NK}-2$ receptors expressed in nodose somata after antigenic challenge are also G-protein-coupled, modification of a regulatory site on the receptor, the G-protein, or the ion channel could allow recoupling. Wherever this site is located, its modification must have a relatively long half-life, because unmasking of tachykinin receptors lasts for days.

\section{Physiological relevance of unmasked NK-2 receptors}

Many of the somata in the guinea pig nodose ganglia are immunopositive for SP and NKA (Kummer et al., 1992; Fischer et al., 1996), and there is functional evidence that tachykinins are released from airway vagal afferents (Canning and Undem, 1993; Lundberg, 1995). Thus, if NK-2 receptors are unmasked after allergic inflammation near nerve endings of tachykininergic neurons, they could subserve an excitatory autoreceptor function, perhaps contributing to the development of primary hyperalgesia or airway hyper-reactivity. In this regard, it is interesting to note that in models of inflammation, tissue inflammation, or treatment with inflammatory mediators, $20-50 \%$ of unresponsive ("silent") C-fiber afferents can be recruited to fire action potentials to thermal or mechanical stimuli (Handwerker, 1976; McMahon and Koltzenburg, 1990). Although it is not yet known whether tachykininergic vagal afferents also exist as silent nociceptors, the unmasking of functional NK-2 receptors would be an ideally suited mechanism for "awakening" such nociceptors.

It is more difficult to envisage a physiological or pathophysiological role for NK-2 receptor expression on somal membranes. It is not apparent which structures in the nodose ganglia would secrete tachykinins to activate somal receptors, because synaptic profiles are not evident in nodose ganglia (Lieberman, 1976). Approximately $25 \%$ of the nodose cell bodies are, however, immunopositive for SP and NKA (Kummer et al., 1992; Fischer et al., 1996); consequently, these structures could be a potential source for tachykinin release. Depolarization- and $\mathrm{Ca}^{2+}$. dependent exocytosis of SP can be demonstrated in isolated dorsal root ganglion neurons (Huang and Neher, 1996), additionally $\mathrm{Ca}^{2+}$-dependent somatic release of serotonin (Fueri et al., 1984) or acetylcholine (Palouzier-Paulignan et al., 1992) occurs in a small population $(\sim 3 \%)$ of cat and rabbit nodose ganglion neurons, respectively. Thus, the unmasking of tachykinin receptors on soma membranes may provide additional pathways for autocrine and paracrine signaling between neurons of the nodose ganglia.

\section{REFERENCES}

Albuquerque AAC, Leal-Cardoso JH, Weinreich D (1996) Antigeninduced synaptic plasticity in sympathetic ganglia from actively and passively sensitized guinea pigs. J Auton Nerv Syst 61:139-144.

Barnes PJ, Belvisi MG, Rogers DF (1990) Modulation of neurogenic inflammation: novel approaches to inflammatory disease. Trends Pharmacol 11:185-189.

Brown D, Katsura K, Megumi K, Verkman AS, Sabolic I (1995) Cellular distribution of the aquaporins: a family of water channel proteins. Histochem Cell Biol 104:1-9.

Canning BJ, Undem BJ (1993) Relaxant innervation of the guinea-pig trachealis: demonstration of capsaicin-sensitive and -insensitive vagal pathways. J Physiol (Lond) 460:719-739.

Christian EP, Undem BJ, Weinreich D (1989) Endogenous histamine excites neurones in the guinea-pig superior cervical ganglion in vitro. J Physiol (Lond) 409:297-312.

Christian EP, Togo JA, Naper KE, Koschorke G, Taylor G, Weinreich D (1993) A retrograde labeling technique for the functional study of airway-specific visceral afferent neurons. J Neurosci Methods 47:147-160.

Cohen AS, Moore KA, Bangalore R, Jafri MS, Weinreich D, Kao JPY (1997) $\mathrm{Ca}^{2+}$-induced $\mathrm{Ca}^{2+}$ release mediates $\mathrm{Ca}^{2+}$ transients evoked by single action potentials in rabbit vagal afferent neurones. J Physiol (Lond) 499:315-328.

Emonds-Alt X, Vilain P, Goulaouic P, Proietto V, Van Broeck D, Advenier C, Naline E, Neliat G, Le Fur G, Breliere JC (1992) A potent and selective nonpeptide antagonist of the neurokinin $\mathrm{A}\left(\mathrm{NK}_{2}\right)$ receptor. Life Sci 50:101-106.

Fischer A, McGregor GP, Saria A, Philippin B, Kummer W (1996) Induction of tachykinin gene and peptide expression in guinea pig nodose primary afferent neurons by allergic airway inflammation. J Clin Invest 98:2284-2291.

Ford-Hutchinson AW, Gresser M, Young RN (1994) 5-Lipoxygenase. Annu Rev Biochem 63:683-417.

Fueri C, Faudon M, Hery M, Hery F (1984) Release of serotonin from perikarya in cat nodose ganglia. Brain Res 304:173-177.

Garland AM, Grady EF, Lovett M, Vigna SR, Frucht MM, Krause JE, Bunnett NW (1996) Mechanisms of desensitization and resensitization of $\mathrm{G}$ protein-coupled neurokinin ${ }_{1}$ and neurokinin ${ }_{2}$ receptors. Mol Pharmacol 49:438-446.

Greene R, Weinreich D, Fowler JC, MacGlashlan D (1988) IgEchallenged human lung mast cells excite sensory neurons in vitro. J Appl Physiol 64:2249-2253.

Grynkiewicz G, Poenie M, Tsien RY (1985) A new generation of $\mathrm{Ca}^{2+}$ indicators with greatly improved fluorescence properties. J Biol Chem 260:3440-3450.

Handwerker HO (1976) Influences of algogenic substances and prostaglandins on the discharges of unmyelinated cutaneous nerve fibers identified as nociceptors. In: Advances in pain research and therapy, Vol 1. (Bonica JJ, Albe-Fessard D, eds), pp 41-45. New York: Raven.

Huang L-YM, Neher E (1996) $\mathrm{Ca}^{2+}$-dependent exocytosis in the somata of dorsal root ganglion neurons. Neuron 17:135-145.

Inoue K, Nakazawa K, Inoue K, Fujimori K (1995) Nonselective cation channels coupled with tachykinin receptors in rat sensory neurons. J Neurophysiol 73:736-742. 
Kakehata S, Yamamoto T, Takasaka T, Akaike N (1995) Suppression of a nonselective cation conductance by substance $\mathrm{P}$ in cochlear outer hair cells. Am J Physiol 38:1185-1192.

Kao JPY (1994) Practical aspects of measuring $\left[\mathrm{Ca}^{2+}\right]$ with fluorescent indicators. In: Methods in cell biology, Vol 40, A practical guide to the study of calcium in living cells (Nuccitelli R, ed), pp 155-181. New York: Academic

Kummer WA, Fischer R, Kurkowski R, Heym C (1992) The sensory and sympathetic innervation of guinea pig lung and trachea as studied by retrograde neuronal tracing and double-labeling immunohistochemistry. Neuroscience 49:715-737.

Lieberman AR (1976) Sensory ganglia. In: The peripheral nerve. (Landon DN, ed), pp 188-278. London: Chapman and Hall.

Lundberg JM (1995) Tachykinins, sensory nerves, and asthma-an overview. Can J Physiol Pharmacol 73:908-914.

Maggi CA (1995) Tachykinin receptors. In: G-protein coupled transmembrane signal mechanisms (Ruffolo Jr RR, Hollinger MA, eds), pp 95-151. Boca Raton, FL: CRC.

Mantyh PW, Allen CJ, Ghilardi JR, Rogers SD, Mantyh CR, Liu H, Basbaum AI, Vigna SR, Maggio JE (1995) Rapid endocytosis of a G protein-coupled receptor: substance P-evoked internalization of its receptor in the rat striatum in vivo. Proc Natl Acad Sci USA 92:2622-2626.

Marshall JS, Waserman S (1995) Review: mast cells and the nervespotential interactions in the context of chronic disease. Clin Exp Allergy 25:102-110.

McLean S, Lowe III JA (1994) Agonist and antagonist receptor binding. In: The tachykinin receptors (Buck SH, ed), pp 67-99. Totowa, NJ: Humana.

McMahon SB, Koltzenburg M (1990) Novel classes of nociceptors: beyond Sherrington. Trends Neurosci 13:199-201.

Meyer RA, Campbell JN, Raja SN (1994) Peripheral neural mechanisms of nociception. In: Textbook of pain (Wall PB, Melzack R, eds), pp 13-44. New York: Churchill Livingstone.

Nakajima Y, Nakajima S (1994) Signal transduction mechanisms of tachykinin effects on ion channels. In: The tachykinin receptors (Buck SH, ed), pp 285-327. Totowa, NJ: Humana.

Neumann S, Doubell TP, Leslie T, Woolf CJ (1996) Inflammatory pain hypersensitivity mediated by phenotypic switch in myelinated primary sensory neurons. Nature 384:360-364.

Otsuka M, Yoshioka K (1993) Neurotransmitter functions of mammalian tachykinins. Physiol Rev 73:229-308.

Oury-Donat F, Carayon P, Thurneyssen O, Pailhon V, Emonds-Alt X,
Soubrie P, Le Fur G (1995) Functional characterization of the nonpeptide neurokinin3 (NK3) receptor antagonist, SR142801 on the human NK3 receptor expressed in Chinese hamster ovary cells. J Pharmacol Exp Ther 274:148-154.

Palouzier-Paulignan B, Chamoin M-C, Ternaux J-P (1992) Somatic acetylcholine release in rabbit nodose ganglion. Eur $\mathrm{J}$ Neurosci 4:1123-1129.

Pedersen KE, Myers AC, Undem BJ (1997) Neuro-immune interactions in airway inflammation. In: Inflammatory mechanisms of asthma (Busse W, Holgate S, eds). New York: Dekker.

Riccio MM, Myers AC, Undem BJ (1996) Immunomodulation of afferent neurons in guinea-pig isolated airway. $\mathbf{J}$ Physiol (Lond) 491:499-509.

Snider RM, Constantine JW, Lowe JA, Longo KP, Lebel WS, Woody HA, Drozda SE, Desai MC, Vinick FJ, Spencer RW, Hess H (1991) A potent nonpeptide antagonist of the substance $\mathrm{P}\left(\mathrm{NK}_{1}\right)$ receptor. Science 251:435-437.

Spiegelman I, Puil E (1990) Ionic mechanism of substance P actions on neurons in trigeminal root ganglia. J Neurophysiol 64:273-281.

Stead RH, Bienenstock J (1990) Cellular interactions between the immune and peripheral nervous systems. A normal role for mast cells? In: Cell to cell interaction (Burger MM, Sordat B, Zinkernagel RM, eds), pp 170-187. Basel: Karger.

Theoharides TC (1996) The mast cell: a neuroimmunoendocrine master player. Int J Tissue React XVIII:1-21.

Undem BJ, Weinreich D (1993) Electrophysiological properties and chemosensitivity of guinea pig nodose ganglion neurons in vitro. J Auton Nerv Syst 44:7-34.

Undem BJ, Hubbard W, Weinreich D (1993) Immunologically-induced neuromodulation of guinea pig nodose ganglion neurons. J Auton Nerv Syst 44:35-44.

Weinreich D, Undem BJ (1987) Immunological regulation of synaptic transmission in isolated guinea pig autonomic ganglia. J Clin Invest 79:1529-1532.

Weinreich D, Wonderlin WF (1987) Inhibition of $\mathrm{Ca}^{2+}$-dependent spike afterhyperpolarization increases excitability of rabbit visceral sensory neurones. J Physiol (Lond) 394:415-427.

Weinreich D, Undem BJ, Taylor G, Barry MF (1995) Antigen-induced long-term potentiation of nicotinic synaptic transmission in the superior cervical ganglion of the guinea pig. J Neurophysiol 73:2004-2016.

Widdop RE, Krstew E, Jarrott B (1990) Temperature dependence of angiotensin II-mediated depolarization of the rat isolated nodose ganglion. Eur J Pharmacol 188:107-111. 